\title{
Glutamine alone or combined with short-chain fatty acids fails to enhance gut adaptation after massive enterectomy in rats ${ }^{1}$
}

\author{
Glutamina pura ou combinada com ácidos graxos de cadeia curta não melhora a \\ capacidade adaptativa do intestino após enterectomia extensa em ratos
}

\author{
José de Souza Neves ${ }^{2}$, José Eduardo de Aguilar-Nascimento ${ }^{3}$, Maria Helena Gaiva Gomes-da-Silva ${ }^{4}$, Rosecélia Nunes \\ Cavalcanti $^{5}$, Alberto Salomão Bicudo ${ }^{6}$, Mariana Nascimento ${ }^{6}$, Rubens Jardim Nochi Jr. ${ }^{6}$ \\ 1. Department of Surgery, University of Mato Grosso, Cuiabá, Brazil \\ 2. Master, Assistant Professor, Department of Surgery, Federal University of Mato Grosso, Brazil \\ 3. MD, PhD, Chairman Full Professor, Department of Surgery, Federal University of Mato Grosso, Brazil \\ 4. PhD, Associate Professor, Department of Nutrition and Dietetics, Federal University of Mato Grosso, Brazil \\ 5. Biologist of Julio Muller Hospital, Federal University of Mato Grosso, Brazil \\ 6. MD, Department of Surgery, Federal University of Mato Grosso, Brazil
}

\begin{abstract}
Purpose: To investigate the effect of oral glutamine alone or combined with short chain fatty acids (SCFA) in the intestinal adaptation of rats submitted to an massive enterectomy. Methods: After receiving 70\% small bowel resection, 30 Wistar rats were randomized to received either standard rat chow (control group, $n=10$ ) or the same diet supplemented with $3,05 \%$ of glutamine alone (glutamine group, $\mathrm{n}=10$ ) or combined with a solution containing SCFA (glutamine+SCFA group, $\mathrm{n}=10$ ) . Animals were killed on the $14^{\text {th }}$ postoperative day. Mucosal weight, crypt depth, villus height, wall width, and the mucosal content of DNA, were assessed in basal conditions (resected gut specimen) and compared to the small bowel specimen collected on the postoperative day 14, at both jejunum and ileum sites. Results: All groups presented similar pattern in weight evolution. In all groups, both the morphological findings and the DNA content were significantly higher at the end of the experiment than in basal conditions, at both the jejunum and ileum. Except for the jejunum wall width that was higher in control group $(808 \pm 95 \mu)$ than in the other two groups (glutamine $=649 \pm 88 \mu$ and glutamine $+\mathrm{SCFA}=656 \pm 92 ; \mathrm{p}<0.01$ ), there was no difference among them in all variables at both intestinal sites after 14 days. Conclusion- All groups presented adaptation of the intestinal mucosa in the remnant gut. Glutamine combined or not with short chain fatty acids fails to influence the adaptive response of the small bowel.
\end{abstract}

Key words: Glutamine. Fatty acids. Butyrates. Intestinal Mucosa. Intestine, small. Nutrition.

\section{RESUMO}

Objetivo: Investigar o efeito da glutamina oral isolada ou associada a ácidos graxos de cadeia curta (SCFA) na adaptação intestinal de ratos submetidos a resseção extensa. Métodos: Após ressecção de 70\% do intestino delgado, 30 ratos Wistar foram randomizados para receber uma dieta padrão (grupo controle, $n=10$ ) ou a mesma dieta suplementada com $3,05 \%$ de glutamina (grupo glutamina, $\mathrm{n}=10$ ) ou combinada com SCFA (grupo glutamina+SCFA, $\mathrm{n}=10$ ). Os animais foram sacrificados no $14^{\circ}$ dia de PO. Foram estudados: peso da mucosa, profundidade da cripta, altura do vilo, espessura da parede e conteúdo de DNA no jejuno e no íleo, em condição basal e no dia do sacrifício. Resultados: O peso evoluiu da mesma forma nos 3 grupos. No final do experimento todos os parâmetros morfológicos e o DNA aumentarem significantemente. Com exceção a espessura da parede do jejuno que foi mais alta no grupo controle $(808 \pm 95 \mu)$ que nos outros dois grupos (glutamina $=649 \pm 88 \mu$ e glutamina $+\mathrm{SCFA}=656 \pm 92 ; \mathrm{p}<0.01$ ), não houve diferença entre os grupos em todas as variáveis no $14^{\circ}$ dia. Conclusão: A adaptação intestinal ocorreu em todos os grupos. Glutamina isolada ou associada a SCFA não influencia a resposta adaptativa do intestino delgado.

Descritores: Glutamina. Ácidos Graxos. Butiratos. Mucosa Intestinal. Intestino Delgado. Nutrição.

\section{Introduction}

The management of short-bowel syndrome (SBS) is still a challenge for surgeons, gastroenterologists, dietitians and pediatritians ${ }^{1,2}$. The prognosis is dependent on the extension of the segment ressected as well as on the involvement of the colon and the ileo-cecal valve ${ }^{3}$. After extensive enterectomy, the remnant bowel usually dilates and elongates. The bowel wall become thick and microscopically occurs an adaptation of the mucosa characterized by an increase of the crypt depth and villus height. In summary, there is an enhancement of the crypt cell proliferation rate $^{1}$. Moreover, it occurs an improvement of the absorptive capacity of the bowel due to a better activity of the brush border enzymes ${ }^{4,5}$. The trophism of the bowel mucosa is dependent of intraluminal factors including 
the presence of nutrients ${ }^{6}$. Although glutamine is the best fuel for the enterocyte, there is evidence from the literature that the small bowel mucosa can absorb short-chain fatty acids (SCFA). SCFA, especially butyrate, are the best fuel for colonocytes contributing $70 \%$ for the colonic mucosa cell energy ${ }^{7,8}$. Some authors have reported controversial effects of glutamine during intestinal adaptation in SBS. Although most of these articles reports enhancement of bowel adaptation by either intravenous or enteral routes ${ }^{9}$, some others have shown no effect of glutamine in either experimental or clinical setting ${ }^{10,11}$. Few articles reported the use of SCFA aiming to improve intestinal adaptation in SBS. SCFA by either intravenous or intra-cecal route were equally effective to restore intestinal trophism ${ }^{12-14}$. However, oral route of administration of SCFA has never been tested in animal models of SBS. The association of glutamine and SCFA to improve intestinal adaptation in SBS has thus, scientifical grounds to be tested. Therefore the aim of this study was to investigate the effect of glutamine alone or associated with SCFA on the intestinal adaptation in an animal model of SBS.

\section{Methods}

\section{Animals}

Thirty male Wistar $(241 \pm 3 \mathrm{~g})$ entered the experiment. After a period of three days of adaptation at the laboratory environment receiving standard rat chow (basic composition: $22 \mathrm{~g}$ of nitrogen $/ \mathrm{kg}, 5 \%$ fiber containing corn, dextrin, sacarose, soybean, casein, in addition of vitamins and minerals) and water ad libitum, they were submitted to $70 \%$ small bowel resection followed by one-layer end-toend anastomosis.

\section{Operative technique}

The rats underwent $4 \mathrm{~cm}$ median laparotomy under general anesthesia with inhalatory ether. The small bowel was measured and the $70 \%$ medial portion was ressected. The equivalent remnant portions of jejunum and ileum (approximately $10 \mathrm{~cm}$ in each side) were anastomosized with 5-0 interrupted nylon sutures. Then the cavity was closed in two plans of interrupted non-absorbable nylon sutures.

\section{Histomorphometry}

Full-thickness biopsies of the two extremities of the specimens (jejunum and ileum sites) were collected in $10 \%$ formalin and sent to laboratory to histomorphometry. Histological sections cut sagitally to the serosa were stained with hematoxylin and eosin and studied by an observer blinded to the animal groups. Crypt depth (CD), villus height $(\mathrm{VH})$ and intestinal wall width (WW) were measured (in $\mu \mathrm{m})$ on each slide using a micrometer rule (Olympus, Japan). The mean value of the ten best-oriented crypts was considered to represent the data for each specimen. WW, measured at the same site as CD, was defined as the distance from the serosa to the lumen.

\section{DNA content}

The rest of the small bowel specimen was opened longitudinally and two segments of approximately $15 \mathrm{~cm}$ in both extremities were selected to represent the jejunum and ileum in each animal. In these sites, the entire mucosa was stripped out using a glass slide, weighted and assayed for DNA content ${ }^{15}$.

\section{Evolution of body weight}

Animals were weighted in five periods during the development of the experiment as follows: day -3 : adaptation period; day 0: operation day; and on the 4th, 9 th and 14 th post-operative day.

\section{Groups and post-operative care}

After the operation the animals were set in individual metabolic cages and randomized to three groups of 10 rats each to receive either the same diet (control group) or the same diet supplemented with $3 \mathrm{~g}$ of glutamine (Support, Rio de Janeiro, Brazil) per $100 \mathrm{~g}$ of the diet (glutamine group) alone or combined with a solution containing short-chain fatty acids (glutamine + SCFA group). The three diets were isocaloric (approximately $345 \mathrm{kal} / 100 \mathrm{~g}$ of diet) and isonitrotrogeneous $(2.24 \mathrm{gN} / 100 \mathrm{~g}$ of diet). The SCFA solution was mixed with bi-distilled water, and contained 15 $\mathrm{mM}$ sodium propionate, $35 \mathrm{mM}$ of sodium acetate and 9 mM sodium N'-butyrate (Sigma Chemical Co., St. Louis, MO, USA). The solution was adjusted to an osmolarity of $113 \mathrm{mOsm}$ by the addition of $\mathrm{NaCl}$ and then to a $\mathrm{pH}$ of 7.0 with either concentrated $\mathrm{NaOH}$ or $\mathrm{HCl}$ as appropriate ${ }^{16}$. Animals that died during the experiment were replaced with others. The amount of food ingested was registered every day. For statistical purposes the mean value of the ingested chow of each animal was analyzed in four phases: 1: from day -3 to day 0 ; phase 2 : from the $1^{\text {st }}$ to the $4^{\text {th }}$ post-operative day; phase 3 : from the $3^{\text {rd }}$ to the $5^{\text {th }}$ post-operative day; and phase: 4: from the do $10^{\text {th }}$ to the $14^{\text {th }}$ post-operative day. Animals were seen every day, weighted in specific dates and operated on again on the 14 th post-operative day. The remnant small bowel was ressected and freed from adhesions and the mesentery. The specimen was measured and opened as explained before. The same method of collection of tissue samples from both the jejunum and ileum was done again and sent for both histomorphometry and DNA assay as described.

\section{Statistical analysis}

Comparisons between the three groups were performed with two-way Anova test after assessing homogeneity of the samples by the Levene's test. When a significant level occurred, differences among groups were identified using the Tukey's test. Comparisons of data from basal conditions (intraoperative specimens) with post-operative day 14 specimens in each group were done with paired Student's t test. A significant level of $5 \%(p<0.05)$ was established. The data were reported as mean \pm SD. The SSPS (Statistical Package for Social Sciences) version 8.0 was used for statistical calculation. 


\section{Results}

\section{Amount of consumed food}

The amount of food consumed by the animals of the three groups was equivalent and did not statistically differ between groups and phases (Table 1). The mean oral intake of distilled water plus SCFA was $23 \pm 1 \mathrm{ml} /$ day equivalent to $0.12 \mathrm{~g} /$ day of SCFA. The mean glutamine ingested was $0.45 \pm 0.03 \mathrm{~g} /$ day in glutamine group and $0.48 \pm 0.03 \mathrm{~g} /$ day in glutamine + SCFA group $(\mathrm{p}>0.05)$.

TABLE 1 - Consumption of food according to groups and phases. Data are mean \pm SD.

\begin{tabular}{ccccc}
\hline & \multicolumn{4}{c}{ GROUP } \\
\cline { 2 - 4 } PHASE & CONTROL & GLUTAMINE & $\begin{array}{c}\text { GLUTAMINE } \\
\text { PLCFA }\end{array}$ \\
\hline 1 & $14.3 \pm 2.4$ & $14.2 \pm 0.6$ & $14.7 \pm 0.7$ & 0.49 \\
2 & $13.1 \pm 0.8$ & $13.6 \pm 0.4$ & $13.1 \pm 0.8$ & 0.24 \\
3 & $16.1 \pm 0.8$ & $15.2 \pm 4.4$ & $15.1 \pm 1.7$ & 0.71 \\
4 & $15.9 \pm 1.1$ & $15.9 \pm 1.1$ & $16.6 \pm 0.8$ & 0.34 \\
\hline
\end{tabular}

\section{Weight evolution}

There was no statistical difference between the groups in body weight evolution in all periods. All animals significantly loose weight from day -3 to day 0 . They continued to loss weight until the postoperative day 4 when recovery begun in all groups. However, only glutamine+SCFA animals significantly loose weight from day 0 to day 4 , and only control rats significantly gain weight from day 9 to day 14 (Figure 1).

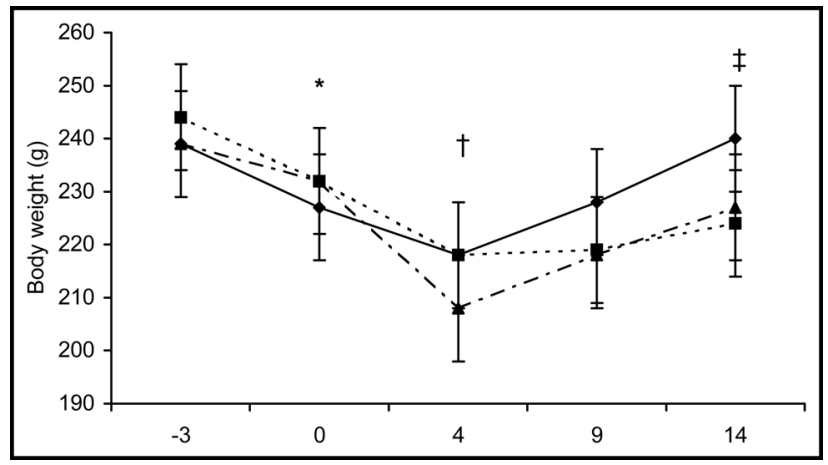

FIGURE 1 - Body weight of control (solid line), glutamine (dotted line) or glutamine + SCFA (dottedsolid line) animals over time. Values are means with their standard deviation represented by vertical bars. Not significant difference in comparison among groups. $*=p<0.05$ vs. day -3 in all groups; $\dagger=p=0.01$ vs. day 0 in glutamine + SCFA group; $\$=p=0.04$ vs. day 9 in control group.

\section{Mucosal weight}

In all groups the post-operative mucosal weight was significantly heavier than the basal condition specimens in both the jejunum and ileum sites. There was no statistical difference when the three groups were compared (Figure 2).



FIGURE 2 - Mean (SD) of mucosal weight in the three groups in basal condition (BC) and postoperatively (PO) at the jejunum (JEJ) and ileum (ILE). * ${ }^{*} \mathrm{p}$ $<0.01$ vs. pre in each group at the jejunum. $\dagger=$ $\mathrm{p}<0.01$ vs. pre in each group at the ileum. GLN $=$ glutamine group; GLN $+\mathrm{SCFA}=$ glutamine+SCFA group.

\section{Histomorphometry}

The findings of crypt depth, villus height and wall width can be seen in figures $3 \mathrm{~A}, \mathrm{~B}$ and C. In all groups, the postoperative values were higher than the basal values in both the jejunum and ileum sites. There was no difference among the groups when compared except for control animals that presented higher postoperative wall width values than both the other two groups (figure $3 \mathrm{C}$ ). 


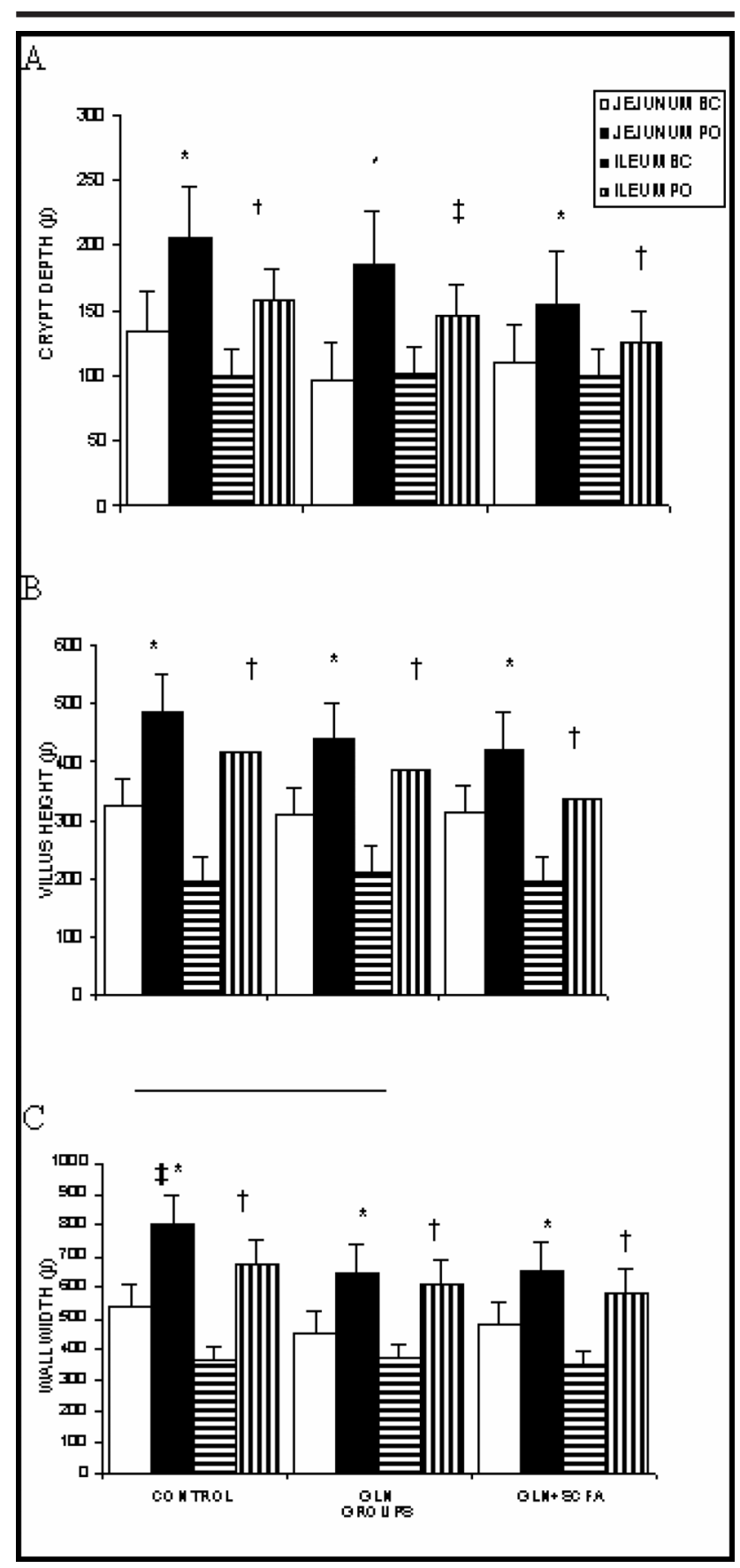

FIGURE 3 - Mean (SD) of crypt depth (A), villus height (B) and wall width $(\mathrm{C})$ in the three groups in basal condition (BC) and postoperatively (PO) at the jejunum and ileum. $*=p<0.01$ vs. $B C$ in each group at the jejunum. $\dagger=p<0.01$ vs. $B C$ in each group at the ileum. $\ddagger=\mathrm{p}<0.01$ vs. GLN and GLN+SCFA groups at postoperative period. GLN = glutamine group; GLN+SCFA = glutamine+SCFA group.

\section{DNA content}

The mean mucosal DNA content significantly increased from basal condition to postoperative day 14 specimens in both examined sites of the small bowel in all groups. There was no difference among the groups when compared (Figure 4).

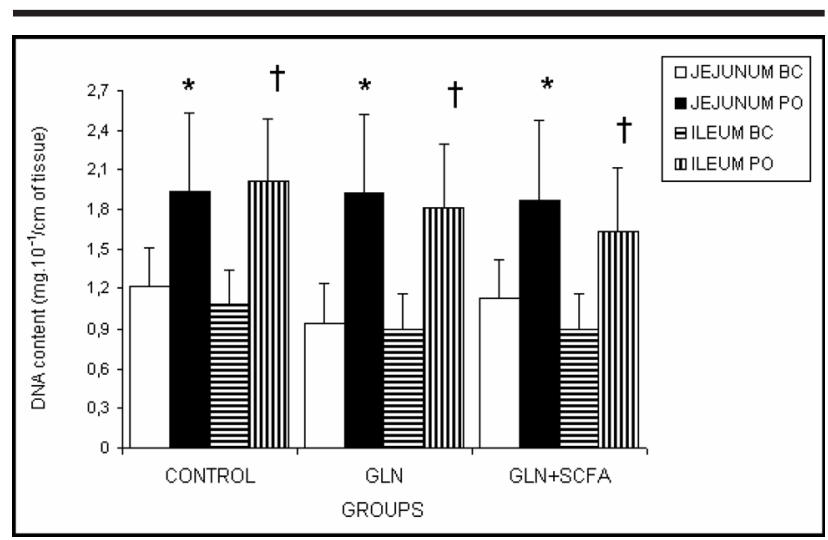

FIGURE 4 - Mean (SD) of the DNA mucosal content in the three groups in basal condition $(\mathrm{BC})$ and postoperatively (PO) at the jejunum and ileum. $*=\mathrm{p}<0.01$ vs. pre in each group at the jejunum. $\dagger=p<0.01$ vs. pre in each group at the ileum. GLN = glutamine group; GLN+SCFA $=$ glutamine + SCFA group.

\section{Discussion}

The overall results have confirmed the adaptability of the small bowel remnant after extensive resection. All the studied variables were greater 14 days after the resection. However, the two mucosal nutrients failed to enhance the normal course of adaptation in the remnant gut. Nor pure glutamine neither glutamine combined with SCFA increased any of the parameters examined in this study. Not only all the histological variables were not significantly different but also both the mucosal weight and its DNA content were similar in both nutritional groups when compared with the controls. In basal experimental conditions, oral administration of glutamine increases the gut wall width ${ }^{17}$, and both mucosal protein and DNA content ${ }^{18}$. Glutamine is also implicated in diminishing bacterial translocation and gut permeability in some experimental reports ${ }^{19}$. In experimental SBS however, other reports failed to demonstrate a significant improvement of the adaptability of the remnant bowel with enteral glutamine ${ }^{10,11}$. Intravenous glutamine also failed to improve gut morphology after experimental radiation injury ${ }^{20}$. Postoperative enteral bolus glutamine supplementation at a dose of $2 \mathrm{~g} / \mathrm{kg}$ of body weight did not enhance the adaptation of the residual intestine 10 days after massive intestinal resection in the rat. In fact, a study has shown that glutamine-enriched enteral nutrition produced little effect in body mass, plasma IGF-I level, and remnant small bowel mucosal structure ${ }^{21}$. Intravenous route of glutamine also seems to fail in improve adaptation of the small bowel. Although intravenous glutamine may enhance the gut-trophic effect of the growth hormone, gut adaptation seems possible only with growth hormone alone and not with pure glutamine ${ }^{22}$. Moreover, there was no synergistic effect between growth hormone and glutamine in improvement of whole body anabolism in that animal model ${ }^{23}$. In the clinical setting however, it has been reported good results with the association of both growth hormone and glutamine in the treatment of patients with SBS ${ }^{9}$. This finding may express the anabolic effect of 
the growth hormone that may be enhanced by the nutritional effect of the glutamine on the epithelial cells of the small bowel $^{22}$. The central idea of this experiment was to investigate the effect of glutamine, the best nutrient for enterocytes, pure or combined with SCFA. SCFA is the best fuel for colonocytes and may contribute as energy supply for small bowel epithelial cells. Our findings failed to demonstrate any increase of benefits on gut adaptation associated with the addition of oral SCFA plus glutamine on the diet. The effect of SCFA in SBS is poorly known. In experimental bases, SCFA induce rapid changes in ileal proglucagon and glucose transporter expression in rats receiving TPN and provide insights into therapeutic management of individuals with SBS ${ }^{24}$. Tappenden et $a l^{25}$ have shown better functional results during adaptation in experimental SBS with intravenous SCFA added to TPN. Tappenden et al also demonstrated that systemic administration of SCFA increases mucosal, and submucosal weights both 3 and 7 days after surgery. The ileal DNA and RNA concentrations were also increased in the SCFA group at both time points; however ileal protein concentration did not differ between groups until 7 days after resection ${ }^{26}$. The lack of benefit associated with SCFA in this study may be due to the oral route. In animal models of extensive resection, the oral route of administration of SCFA has never been investigated. However, oral administration of SCFA in doses close to physiological proportions may reduce both the inflammation and necrosis in animal model of intestinal mucositis due to Ara-C in mice fed commercial or elemental $\operatorname{diets}^{27}$. Other experiments have evaluated the effects of enteral administered SCFA after intestinal resection. Intracecal SCFA supplementing TPN in rats underwent $80 \%$ enteral resection have shown an improvement of the intestinal adaptation when compared with TPN alone ${ }^{28}$. Kripke et $a l^{12}$, have supplemented an elemental diet with short-chain tryglicerids in rats underwent $60 \%$ distal smallbowel resection. They observed an improvement on the jejunal and colonic adaptation growth, and comparable nutritional status with the controls that received either normal diet or medium-chain tryglicerids. However, in another experiment, an increase formation of SCFA on small bowel segment was not associated with locally trophic effects $^{29}$. Further studies comparing intra luminal and intravenous routes for SCFA administration are then mostly required. Our data did not show any advantageous effect of glutamine in intestinal adaptation after massive bowel resection, and the addition of oral SCFA to glutamine did not promote any additional benefit. In conclusion, the experimental adaptive response in the intestinal remnant after extensive resection is not influenced by oral supplementation of glutamine alone or combined with SCFA.

\section{References}

1. Sencan A, Mir E, Karaca I, Akcora B, Ozer E. Effects of intrinsic denervation on intestinal morphology in rats with short-bowel syndrome. Pediatr Surg Int. 2000; 16:554-8.

2. Iglesias ACRG. Surgical management of short-bowel syndrome. Acta Cir Bras. 1995; 10:135-43.
3. Dudrick SJ, Lafiti R, Fosnocht DE. Management of short bowel syndrome. Surg Clin North Am. 1991; 71:625-43.

4. Koruda MJ, Rolandelli RH, Settle RG, Saul SH, Rombeau JL. The effect of a pectin-supplemented elemental diet on intestinal adaptation to massive small bowel resection. J Parenter Enteral Nutr. 1986; 10:343-50.

5. Scolapio JS, Fleming CR. Short-bowel syndrome. Gastroenterol Clin North Am. 1998; 37:467-9.

6. Feldman EJ, Dowling RH, Mc Naughton J, Peters TJ. Effects of oral versus intravenous nutrition on intestinal adaptation after small bowel resection in dog. Gastroenterology. 1976; 70:712-9.

7. Bergman EN. Energy contributions of volatile fatty acids from the gastrointestinal tract in various species. Physiol Rev. 1990; 70:567-83.

8. Cook SI, Sellin JH. Review article: short-chain fatty acids in health and disease. Aliment Pharmaco. Ther. 1998; 12:499-507.

9. Byrne TA, Persinger RL, Young LS, Ziegler TR, Wilmore DW. A new treatment for patients with short-bowel syndrome. Growth hormone, glutamine and a modified diet. Ann Surg. 1995; 222:243-55.

10. Michail S, Mohammadpour H, Park JH, Vanderhoof JA. Effect of glutamine-supplemented elemental diet on mucosal adaptation following bowel resection in rats. $\mathrm{J}$ Pediatr Gastroenterol Nutr. 1995; 21:3948.

11. Wiren ME, Permet J, Scullman SP, Wang F, Larsson J. No differences in mucosal adaptive growth one week after intestinal resection in rats given enteral glutamine supplementation or deprived of glutamine. Eur J Sur. 1996 ; 162:489-98.

12. Kripke SA, De Paula JA, Berman JM, Fox AD, Rombeau JL, Settle RG. Experimental short-bowel syndrome: effect of an elemental diet supplemented with short-chain triglycerids. Am J Clin Nutr. 1991; 53:954-62.

13. Koruda MJ, Rolandelli RH, Bliss DZ, Hastings J, Rombeau JL, Settle RG. Parenteral nutrition supplemented with short- chain fatty acids: effect on the small-bowel mucosa in normal rats. Am J Nutr. 1990; 51:685-9.

14. Pratt VC, Tappenden KA, Mc Burney MI. Short chain fatty acids supplemented total parenteral nutrition improve nonspecific immunity after intestinal resection in rats. JPEN J Parenter Enteral Nutr. 1996; 20:264-71.

15. Giles KW, Myers A. An improved diphenylamine method for the estimation of deoxyribonucleic acid. Nature. 1965; 4:206-93.

16. Ramos MG, Bambirra EA, Nicoli JR, Cara DC, Vieira EC, Alvarez-Leite J. Protection by short-chain fatty acids against 1-beta-D-arabinofuranosylcytosine-induced intestinal lesions in germfree mice. Antimicrob Agents Chemother. 1999; 43:950-3.

17. Wilmore DW, Smith RJ, O'Dwyer ST, Jacobs DO, Ziegler TR. The gut: a central organ after surgical stress. Surgery. 1988; 104:917-21.

18. Souba WW, Herskowitz K, Austgen TR, Chen MK, Salloum RM. Glutamine nutrition: theoretical 
considerations and therapeutic impact. JPEN J Parenter Enteral Nutr. 1990; 14:237-41.

19. Rombeau JL. A review of the effects of glutamineenriched diets on experimentally induced enterocolitis. JPEN J Parenter Enteral Nutr. 1990; 14:100-4.

20. Scott TE, Moellman JR. Intravenous glutamine fails to improve gut morphology after radiation injury. JPEN J. Parenter. Enteral. Nutr. 1992; 16:440-4.

21. Yang H, Larsson J, Permert J, BraafY, Wiren M. No effect of bolus glutamine supplementation on the postresectional adaptation of small bowel mucosa in rats receiving chow ad libitum. Dig Surg. 2000; 17:256-60.

22. Zhou X, Li YX, Li N, Li JS. Glutamine enhances the guttrophic effect of growth hormone in rat after massive small bowel resection. J Surg Res. 2001; 99:47-52.

23. Gu Y, Wu ZH. The anabolic effects of recombinant human growth hormone and glutamine on parenterally fed, short bowel rats. World J Gastroenterol. 2002; 8:752-7.

24. Tappenden KA, Drozdowski LA, Thomson AB, McBurney MI. Short-chain fatty acid-supplemented total parenteral nutrition alters intestinal structure, glucose transporter 2 (GLUT2) mRNA and protein, and proglucagon mRNA abundance in normal rats. Am J Clin Nutr. 1998; 68:118-25.
25. Tappenden KA, Thomson AB, Wild GE, Mc Burney MI. Short-chain fatty acid supplemented total parenteral nutrition enhances functional adaptation to intestinal resection in rats. Gastroenterology. 1997; 112:792-802.

26. Tappenden KA, Thomson AB, Wild GE, Mc Burney MI. Short-chain fatty acids increase proglucagon and ornithine descarboxylase messenger RNA, after intestinal resection in rats. JPEN J Parenter Enteral Nutr. 1996; 20: 357-62.

27. Ramos MG, Bambirra EA, Cara DC, Vieira EC, AlvarezLeite JI. Oral administration of short-chain fatty acids reduces the intestinal mucositis caused by treatment with Ara-C in mice fed commercial or elemental diet. Nutr Cancer. 1997; 28:212-21.

28. Koruda MJ, Rolandelli RH, Settle RG, Saul SH, Rombeau JL Effect of parenteral nutrition supplemented with short-chain fatty acids on adaptation to massive smallbowel resection. Gastroenterology. 1998; 95:715-20.

29. Thompson JS, Quigley EM, Palmer JM, West WW, Adrian TE. Luminal short-chain fatty acids and pos-resection intestinal adaptation. JPEN J Parenter Enteral Nutr.1996; 20:338-43.

\section{Correspondence:}

Prof. Dr. José Eduardo de Aguilar-Nascimento

Rua Estevão de Mendonça 81 apto 801

78045-200 - Cuiabá - MT - Brazil

Phone : +55656237183

Fax: +55656234020

e-mail: aguilar@cpd.ufmt.br
Conflict of interest: none

Financial source: none

\section{How to cite this article:}

Neves JS, Aguilar-Nascimento JE, Gomes-da-Silva MHG, Cavalcanti RN, Bicudo AS, Nascimento M, Nochi Jr. RJ. Glutamine alone or combined with short-chain fatty acids fails to enhance gut adaptation after massive enterectomy in rats. Acta Cir Bras. [serial on the Internet] 2006;21 Suppl 4. Available from URL: http://www.scielo.br/acb. 